\title{
Realising the Right to Health for Victims of International Crimes. The Case of Medical Rehabilitation Reparations Ordered by International Courts: Challenges, Possibilities and Ways of Improvement
}

\author{
Juan Pablo Pérez-León Acevedo*
}

DOI: $10.21827 / 5 \mathrm{a} 86 \mathrm{a} 8 \mathrm{~d} 59644 \mathrm{e}$

\author{
Keywords \\ Right to HEALth; ReHABILITATION; REPARATIONS; HARM; InTERNATIONAL CRIMES; \\ SERIOUS HUMAN RIGHTS VIOLATIONS
}

\begin{abstract}
In the last few decades, international crimes, ie, serious human rights violations, have inflicted severe harm on both the physical and mental health of large numbers of victims around the world. In attempting to redress these damages, international courts, within their respective mandates, have issued reparations orders in favour of victims and their communities. Precisely, an important modality of reparations has consisted of rehabilitation which includes measures of a medical nature for victims. This means physical and psychological rehabilitation including treatment, care and support. At three international level courts, namely, the Inter-American Court of Human Rights (IACtHR), International Criminal Court (ICC), and Extraordinary Chambers in the Courts of Cambodia (ECCC), important developments in the field of medical rehabilitative reparations have taken place. This article critically analyses the practices on medical rehabilitation reparations at those courts, suggests which steps should be taken to improve those practices and proposes which actions States and other international community actors should adopt to better implement and/or contribute towards the implementation of orders on medical rehabilitation reparations. Attention is also given to international human rights law, particularly the obligation to cooperate and the right to health standards and principles.
\end{abstract}




\section{Introduction}

The obligation to provide reparations (medical rehabilitation included) as a consequence of a violation of an international obligation is a principle of international law, ${ }^{1}$ and a rule of customary international law. ${ }^{2}$ For example, regional courts, such as the IACtHR and European Court of Human Rights (ECtHR), have implemented this obligation by ordering reparations against States based on their constitutive instruments, for example, the American Convention on Human Rights (ACHR) and the European Convention on Human Rights (ECHR), ${ }^{3}$ in serious human rights violations cases. The Convention against Torture mentions 'full rehabilitation'. ${ }^{4}$ Under the United Nations Basic Principles and Guidelines on the Right to a Remedy and Reparation for Victims of Gross Violations of International Human Rights Law and Serious Violations of International Humanitarian Law (UN Basic Principles and Guidelines), reparations modalities are: 1 . restitution; 2. compensation; 3. rehabilitation; 4. satisfaction; and 5. guarantees of non-repetition. ${ }^{5}$ Under Principle 8, rehabilitation 'should include medical and psychological care'. In this article, the expressions 'rehabilitative reparations' or 'medical rehabilitation' are used interchangeably and include medical and psychological health care.

Reparations, including rehabilitation, are central to the IACtHR's mandate. Victims can claim medical rehabilitation against a State and the IACtHR has the mandate under Article 63(1) of the ACHR to order the defendant State to assure that:

the injured party be ensured the enjoyment of his right or freedom that was violated. It shall also rule, if appropriate, that the consequences of the measure or situation that constituted the breach of such right or freedom be remedied and that fair compensation be paid to the injured party.

International instruments and practice have generally applied the reparations right in the State-individual relation. However, at international/hybrid criminal courts, an individual can claim rehabilitative reparations against another individual. Individuals found guilty shall provide reparations, including rehabilitation, for the harm inflicted on victims. ${ }^{6}$ National and

* Researcher (Abo Akademi University, Finland).

1 Permanent Court of International Justice, Factory at Chorzow, Germany v. Poland, Judgment No. 13 PCIJ Series A No 17, 13 September 1928, 29; International Law Commission, Draft Articles on Responsibility of States for Internationally Wrongful Acts, November 2001, (53d session) A/56/10.

2 International Committee of the Red Cross (ICRC), Customary International Humanitarian Rules, rule 150, see for this: Henckaerts, J M, "Study on International Humanitarian Law", 87(857) International Review of the Red Cross (2005) 198, 211.

3 Article 63(1), Organization of American States, American Convention on Human Rights, 22 November 1969, B-32 (ACHR); Article 41, Council of Europe, European Convention for the protection of Human Rights and Fundamental Freedoms, as amended by Protocols Nos 11 and 14 (1950) ETS 5 (ECHR).

4 Article 14(1), United Nations, Convention against Torture and Other Cruel, Inhuman or Degrading Treatment (1984) 1465 UNTS 85 (CAT).

5 UN General Assembly, Basic Principles and Guidelines on the Right to a Remedy and Reparation for Victims of Gross Violations of International Human Rights Law and Serious Violations of International Humanitarian Law, 16 December 2005, (60th Session) A/RES/60/147, Principles 19-23.

6 Zegveld, L, "Victims' Reparations Claims and International Criminal Courts", 8(1) Journal of International Criminal Justice (2010) 79, 85. 
international practice supports obtaining reparations from individuals claimed by victims before (international) criminal and national civil courts. ${ }^{7}$

The ICC Statute contains the first reparations regime among international/hybrid criminal courts. This is based on Article 75 (Reparations to victims) of the ICC Statute, alongside other dispositions including Article 79 (establishing a Trust Fund for Victims (TFV)) plus ICC Rules of Procedure and Evidence (RPE). Although international/hybrid criminal courts reparations regimes are unique, the ICC and ECCC have considered human rights courts' reparations jurisprudence and the UN Basic Principles and Guidelines. Among the existing international/hybrid criminal courts, the ICC and ECCC are the only ones before which victims may claim (rehabilitative) reparations. Reparations orders can only be made against persons convicted by the ICC and ECCC, ${ }^{8}$ ie, not against States. The implementation of reparations orders may be conducted by the TFV (ICC) or with external funds involving State/non-State cooperation and the Victims Support Section (VSS) (ECCC). The importance of the ICC and ECCC reparations regimes, including rehabilitation, has been highlighted by these courts, ${ }^{9}$ and reparations claimants. ${ }^{10}$

How medical rehabilitative reparations realise the right to health is discussed in the four sections of this Article. The first defines who qualifies as a victim, with regard to the right to health and medical rehabilitative reparations. In the second section, medical rehabilitation as reparation and its implementation are examined. The third evaluates rehabilitative reparations under international human rights law, including, international cooperation/assistance obligation and right to health standards/principles. The fourth section contains final assessments and recommendations.

\section{Defining Victims with Regard to the Right to Health and Medical Rehabilitative Reparations}

\section{II.1. The IACtHR}

Two provisions are relevant in the definition of victims as reparations claimants of rehabilitative measures. First, under the IACtHR Rules of Procedure (Article 2.2.5), the expression 'alleged victim' refers to the person whose rights under the Convention or another treaty of the Inter-American System have been allegedly violated. Second, 'injured parties' (ACHR, Article 63(1)) are those who must receive reparations. Thus, an injured party is an individual who has been declared to be a victim of the ACHR/other Inter-

7 Henckaerts, JM and Doswald-Beck, L, Customary International Humanitarian Law (Cambridge University Press, vol I, Cambridge, 2005), 554-555 (ICRC).

$8 \quad$ Article 75(2), United Nations, Rome Statute of the International Criminal Court (1998) 2187 UNTS 3 (ICC Statute); Rule 23quinquies(1), Extraordinary Chambers in the Courts of Cambodia, Internal Rules (Rev. 9 2015) (ECCC Internal Rules).

9 International Criminal Court (ICC), Lubanga (Decision Concerning Pre-Trial Chamber I's Decision of 10 February 2006 and the Incorporation of Documents into the Record of the Case against Mr Thomas Lubanga Dyilo), ICC-01/04-01/06-8-US-Corr, 24 February 2006, para 136.

10 ECCC, Civil Parties, E125/2, 12 March 2012, para 99. 
American human rights treaties violations, particularly those against torture, enforced disappearance and violence against women.

Cases of serious human rights violations such as widespread and/or systematic practices of torture and other inhumane, cruel and degrading treatment, rape, forced displacement, forced disappearance and extrajudicial execution at the IACtHR, involve serious breaches of, among others, the right to health not only of those directly victimised but also of their loved ones. A major contribution of the IACtHR's case-law to the international law of rehabilitative reparations is the consideration of not only direct victims but also indirect victims. A direct victim is '[a]n individual against whom the illegal conduct of the State agent is directed immediately, explicitly and deliberately'. ${ }^{11}$ It is clear that serious human rights violations breach the core components of the direct victims' right to physical and mental health, generating physical and psychological injuries to be redressed via medical rehabilitation. The right to health of direct victims, ie, those against whom human rights abuses were originally perpetrated, is in the first place seriously violated. In turn, an indirect victim is someone "who does not suffer this illegal conduct in the same way-immediately, directly and deliberately-but who also see his own rights affected or violated from the impact on the so-called direct victim'. ${ }^{12}$

The IACtHR Rules of Procedure authorised both direct victims and also their next of kin to participate autonomously throughout the proceedings to get inter alia rehabilitative reparations. Article 2(15) (previous version) explicitly defined 'next of kin' as: 'the immediate family, that is direct ascendants and descendants, siblings, spouses or permanent companions, or those determined by the Court, if applicable'. References to next of kin were deleted in 2009 to avoid misunderstandings about the scope of potential rehabilitative reparations beneficiaries. This is found appropriate since the definition of indirect victims as rehabilitative reparations beneficiaries may include not only family members provided that there is a proven causal link between the harm inflicted and a violation. As the IACtHR's practice evidences, persons who are not close family members may receive reparations, ${ }^{13}$ rehabilitation included. Close relative members in cases of torture, extrajudicial executions, or enforced disappearance, are entitled to receive rehabilitative reparations in two ways: in their own right, and as heirs, even if they did not participate in the proceedings. ${ }^{14}$

The IACtHR has presumed that close family members or next of kin have suffered on account of the direct victim's harm in cases of enforced disappearance, torture and extrajudicial executions. ${ }^{15}$ Indirect victims suffered psychological injury as a result of the temporary or permanent injury inflicted on their loved ones. ${ }^{16}$ Psychological harm or injury is the consequence of uncertainty or fear about the fate of the direct victim, as well as the indirect victim's knowledge of the direct victim's suffering and/or a loss of sense of safety and moral integrity. ${ }^{17}$

11 Inter-American Court of Human Rights (IACtHR), Ituango Massacres v Colombia, Series C No. 148, 29 June 2006, Separate Concurring Opinion of Judge S. García Ramírez, para 11.

Ibid.

IACtHR, 19 Tradesmen v. Colombia, Series C No. 109, 5 July 2004, para 229.

IACtHR, 'Street Children' et al v Guatemala, Series C No. 77, 26 May 2001, para 67.

IACtHR, La Cantuta v Peru, Series C No. 162, 9 November 2006, para 218.

IACtHR, Bulacio v Argentina, Series C No. 100, 18 September 2003, para 98.

IACtHR, Caracazo v Venezuela, Series C No. 95, 29 August 2002, para 97(b). 
Concerning cases of forced disappearance, which were pandemic for a number of years across Latin America in, among others, Chile, Argentina, Brazil, Peru and Central America, the IACtHR paid special attention to the terrible impact of this heinous State practice on the (mental) health of the families of those disappeared. Due weight was afforded to the anguish, sense of insecurity, frustration and impotence caused by the State authorities' reluctance or failure to investigate and prosecute. ${ }^{18}$ In these appalling circumstances, attacks on victims' mental and moral integrity and, thus, serious violations of their right to health constituted a direct consequence of practices of forced disappearance compounded by the lack of effective investigative or prosecutorial activities. When examining reparations claims, including rehabilitation, the IACtHR has applied a rebuttable presumption whereby the direct victim's direct family members, ie. including parents, children, spouses and permanent companions, have suffered harm as a result of violations of their right to mental and moral integrity, ${ }^{19}$ which compromised their overall health, mental and physical. Thus, the State has the burden of proof to rebut this presumption. This rebuttable presumption is considered important in helping victims get rehabilitative reparations in situations of asymmetric litigation, ie, victims vs State. Where victims who are not direct family members of the direct victim are concerned, they must prove their close relationship with the direct victims. As for them, there is no presumption of their suffering violations of human rights. ${ }^{20}$ Thus, the IACtHR evaluates their situation according to the evidence filed and the case circumstances. The concept of 'family' has many cultural variations and attention should be paid to applicable social and family structures, as reflected in the IACtHR's jurisprudence. ${ }^{21}$

IACtHR's case law has identified physical and mental injury, ${ }^{22}$ emotional suffering, ${ }^{23}$ and economic $\operatorname{loss}^{24}$ as harm to be redressed. Harm may be suffered individually or collectively. ${ }^{25}$ Concerning the causal link between the human rights violation and the harm inflicted, the IACtHR has applied a 'directness' standard. ${ }^{26}$

The IACtHR has approached the scope of beneficiaries of rehabilitative reparations with flexibility and has occasionally accepted a category of beneficiaries not completely defined when rendering its judgment. This approach has been adopted considering the particular circumstances surrounding the cases, especially massacres, and/or indigenous people-related cases. $^{27}$

Members of indigenous communities or massacre victims as a whole have been considered as injured parties for rehabilitative reparations. The IACtHR has undergone an important evolution concerning the way it deals with the scope of reparations beneficiaries, including rehabilitation. The IACtHR was initially quite careful to single out each and every

18 IACtHR, Bámaca Velásquez v Guatemala, Series C No. 70, 25 November 2000, para 160.

19 IACtHR, Valle Jaramillo et al v Colombia, Series C No. 192, 27 November 2008, para 119. See also: Pasqualucci, Jo M, The Practice and Procedure of the Inter-American Court of Human Rights (Cambridge University Press, Cambridge, New York, 2013), 194-195.

$20 \quad$ IACtHR, Kawas Fernández v Honduras, Series C No. 196, 3 April 2009, para 128.

21 IACtHR, Aloeboetoe et al v Suriname, Series C No. 15, 10 September 1993, paras 58-59, 62.

22 IACtHR, Velásquez-Rodríguez v Honduras, Series C No. 4, 29 July 1988, paras 156, 175 and 187.

23 IACtHR, Aloeboetoe et al v Suriname, Series C No. 15, 10 September 1993, para 20.

24 IACtHR, El Amparo v Venezuela, Series C No. 28, 14 September 1996, paras 28-63.

25 IACtHR, Ituango Massacres v Colombia, Series C No. 148, 1 July 2006, para 386.

26 IACtHR, Aloeboetoe et al v Suriname, Series C No. 15, 10 September 1993, para 48.

27 IACtHR, Plan de Sánchez Massacre v Guatemala, Series C No. 116, 19 November 2004, para 92. 
victim and also each and every close member of the direct victim's family member. ${ }^{28}$ However, the IACtHR has progressively recognised the significance of collective rehabilitative reparations for members of victimised communities as a whole. Inter alia the size and geographic diversity of members of victimised indigenous communities and the collective nature of reparations have been considered. The IACtHR found it unnecessary to individualise the members of victimised indigenous communities to recognise them as the injured party and those affected communities have thus been considered as such as collective beneficiaries of reparations, ${ }^{29}$ including rehabilitation.

That the IACtHR no longer always requires to the individualisation of victims when to granting collective reparations at the moment of the judgment is correct. ${ }^{30}$ It normally takes some time for the IACtHR's reparations judgments to be fully known by potential rehabilitative reparations claimants, and all potential individual beneficiaries of collective rehabilitative reparations may not necessarily be identified in cases involving difficult circumstances such as massacres. ${ }^{31}$

\section{II.2. The ICC}

International crimes under the ICC's jurisdiction, ie, genocide, crimes against humanity, war crimes and crime of aggression, inflict severe harm on victims and seriously affect their physical and mental health. The ICC definition of victims is analysed paying attention to the elements most relevant to the right to health and medical rehabilitative reparations. Under Rule 85(a) of the RPE, victims are defined as '(a) [...] natural persons who have suffered harm as a result of the commission of any crime within the jurisdiction of the Court'. Hospitals or other places and objects for humanitarian purposes may also be victims when sustaining 'direct harm to any of their property' (Rule 85(b)). As the immense majority of victims are natural persons, the analysis is limited to them. Concerning the scope of reparations beneficiaries, Trial Chamber I found that:

Pursuant to Rule 85 of the Rules, reparations may be granted to direct and indirect victims, including the family members of direct victims [...]; anyone who attempted to prevent the commission of one or more of the crimes under consideration; and those who suffered personal harm as a result of these offences, regardless of whether they participated in the trial proceedings. ${ }^{32}$

This paragraph reflects the broad scope of potential rehabilitative reparations claimants and beneficiaries. The United Nations Basic Principles and Guidelines, invoked by the ICC

Burgorgue-Larsen, L and Ubeda, A, The Inter-American Court of Human Rights (Oxford University Press, Oxford, 2011), 228 (Burgorgue-Larsen and Ubeda 2011).

29 IACtHR, Plan de Sánchez Massacre v Guatemala, Series C No. 116, 19 November 2004, para 86; IACtHR, Saramaka People v Suriname, Series C No. 172, 28 November 2007, paras 188 and 189. See also: Burgorgue-Larsen and Ubeda 2011, 227-228.

30 Pasqualucci 2013, 195.

$31 \quad I d, 196$.

32 ICC, Lubanga (Decision Establishing the Principles and Procedures to be applied to Reparations, Trial Chamber I), ICC-01/04-01/06-2904, 7 August 2012, para 194. 
Chambers, ${ }^{33}$ contain a definition of victims similar to the ICC Statute's. ${ }^{34}$ Thus, the ICC definition of victims works for rehabilitative reparations purposes.

The victim must be a natural person and prove his or her identity. Rule 89(3) states the possibility for a victim who is a child or a disabled person to have his or her application made by a person acting with his/her consent on his/her behalf. ${ }^{35}$ The list of documents accepted as proof of identity by the ICC has included official, non-official identification documents and other documents and, thus, documents relating to medical treatment have been admitted. ${ }^{36}$

Concerning harm, although Article 75 of the ICC Statute mentions 'damage, loss or injury', there are no further details on the type of harm for reparations. The Appeals Chamber (A.Ch) and Trial Chamber in Lubanga identified physical harm (including reproductive capacity loss), mental and emotional suffering ${ }^{37}$ which are also listed in the participation and reparation standard application form, ${ }^{38}$ and have been considered by the Office of Public Counsel for Victims (OPCV). ${ }^{39}$ Harm can be direct and indirect, ie, harm 'attach to both direct and indirect victims' ${ }^{40}$

Trial Chamber I provided for 'indirect victims', ie, victims who suffered harm as a result of the harm suffered by direct victims, to be included in the reparations scheme. Thus, the ICC has to determine whether there was a close personal relationship between the direct and the indirect victims, for example, the parents of child soldiers. ${ }^{41}$ Moreover, Trial Chamber I appropriately reasoned that since the concept of 'family' presents many cultural variations, the ICC should pay attention to applicable social and family structures, ${ }^{42}$ which is similar to the IACtHR's jurisprudence. Trial Chamber I and the A.Ch established that indirect victims may also include individuals who 'suffered harm when helping or intervening on behalf of direct victims' ${ }^{43}$

Concerning causation for claiming and receiving rehabilitative reparations, ie, the causal link between the crimes for which the accused is convicted and the harm inflicted on the victims,

33 ICC, Lubanga (Judgment on the Appeals of the Prosecutor and The Defense against Trial Chamber I's Decision, on Victims' Participation of 18 January 2008, Appeals Chamber), ICC-01/04-01/06-1432, 11 July 2008, paras 3335.

34 UN General Assembly, Basic Principles and Guidelines on the Right to a Remedy and Reparation for Victims of Gross Violations of International Human Rights Law and Serious Violations of International Humanitarian Law, 21 March 2006, (60th Session) A/RES/60/147, Principle 8 (UN Basic Principles and Guidelines).

35 ICC, Lubanga (Decision on the Applications by Victims to Participate in the Proceedings, Trial Chamber I), ICC01/04-01/06-1556, 15 December 2008, para 67.

36 ICC, Lubanga (Decision on Victims' Participation, Trial Chamber I), ICC-01/04-01/06-1119, 18 January 2008, paras 87-89.

37 ICC, Lubanga (Judgment on the appeals against the "Decision establishing the principles and procedures to be applied to reparations" of 7 August 2012-Order for Reparations, Appeals Chamber), ICC-01/04-01/06-3129-AnxA, 3 March 2015, para 10; ICC, Lubanga (ICC-01/04-01/06-2904) supra nt 32, paras 230 and 231.

38 ICC, Application Form for Individuals. Request for Participation in Proceedings and Reparations, at <icccpi.int/NR/rdonlyres/48A75CF0-E38E-48A7-A9E0-026ADD32553D/0/SAFIndividualEng.pdf> (accessed 17 October 2015).

39 ICC, Lubanga (Observations on Issues Concerning Reparations), ICC-01/04-01/06-2863, 18 April 2012, paras 36-37, 47-60, 62-71.

$40 \quad$ ICC, Lubanga, ICC-01/04-01/06-3129-AnxA supra nt 37, para 6.

41 ICC, Lubanga, (ICC-01/04-01/06-2904) supra nt 32, para 195.

$42 \quad$ Ibid.

$43 \quad I d$, para 196; Lubanga, ICC-01/04-01/06-3129-AnxA supra nt 37, para 6. 
Rule 85(a) does not provide a 'direct' legal causation standard as it only lays down that 'victims' are those who have suffered harm 'as a result' of the commission of a crime within the ICC's jurisdiction. ${ }^{44}$ Indeed, the A.Ch noted that this 'does not necessarily imply the existence of direct harm' ${ }^{45}$ Trial Chamber I closely examined the situation of victims of sexual violence. ${ }^{46}$ Unlike the IACtHR which has applied the 'immediate effects' standard, Trial Chamber I considered that reparations should not be limited to 'direct harm' or 'the immediate effects' of the crimes, and instead applied a proximate cause standard, ${ }^{47}$ as the A.Ch confirmed. ${ }^{48}$

The damage, loss and injury constituting the basis for rehabilitative reparations claims must have resulted from the crimes upon which the accused was convicted. ${ }^{49}$ In applying the 'proximate cause' standard, reparations should not be limited to 'direct harm or immediate effects'.$^{50}$ However, it is necessary to adopt precautions to avoid denaturalising the casebased reparations regime and to avoid a highly exponential increase in reparations claimants and beneficiaries who can render the ICC reparations system inefficient.

The TFV established that '[...] victims who suffered harm from sexualized violence occurring during their enlistment, conscription, or use to participate actively in hostilities as children under the age of 15 are entitled to reparations addressing this specific harm'. ${ }^{51}$ However, the A.Ch did not consider sexual and gender-based violence as harm resulting from the crimes for which Lubanga was convicted. ${ }^{52}$ Considering that there is no direct causal link requirement before the ICC and that this sexual exploitation was arguably linked to the child soldier-related crimes for which Lubanga was convicted, the A.Ch should have upheld the Trial Chamber's finding of reparable harm from sexual and gender violence. This would have been important to redress some specific dimensions of the harm which affected victims' mental and physical health and was caused by sexual/gender violence.

The application process for reparations is individualised, which means that each victim must file a separate reparations request form. However, the type of harm/injury inflicted on a large number of victims may be of a collective nature. Rule 94(1) lists the requirements and items for victims who want to claim reparations. Those directly related to the right to health and medical rehabilitative measures are a 'description of the injury, loss or harm' and 'claims for rehabilitation and other forms of remedy'. ${ }^{53}$ Submissions by legal representatives of victims have included, inter alia, individual and collective reparations as well as modalities of reparations, including rehabilitation, as examined later. Press, Cambridge, 2012), 150.

ICC, Lubanga (Observations of the Trust Fund for Victims 249. Establishing the Principles and Procedures to be Applied to Reparations"), ICC-01/04-01/06-3009, 8 April 2013, para 158.

52 ICC, Lubanga, ICC-01/04-01/06-3129 supra nt 37, paras 196-198.

53 RPE, rules $94(1)(b)$ and (f). 
Rehabilitative reparations awards must identify victims eligible to benefit from rehabilitative reparations or set out the eligibility criteria based on the link between the harm suffered by the victims and the crimes for which the accused was convicted. ${ }^{54}$ The A.Ch considered that when a rehabilitative reparations award benefits a community, only members of the community meeting the relevant criteria are eligible. ${ }^{55}$ Thus, the A.Ch's approach is more limited than the IACtHR's as the latter has ordered rehabilitative awards for entire affected communities.

\section{II.3. The ECCC}

The ECCC has jurisdiction over international and domestic crimes committed by senior Khmer Rouge leaders. To become a civil party and claim rehabilitative reparations before the ECCC, victims according to internal rule 23bis(1) must: 'demonstrate that as a direct consequence of at least one of the crimes alleged against the Charged Person, that he or she has in fact suffered physical, material or psychological injury upon which a claim of collective and moral reparation might be based'. Civil parties' interests 'are principally the pursuit of reparations' provided that there is a criminal conviction. ${ }^{56}$ Under the ECCC rules, victims are entitled to '[s]eek collective and moral reparations', ${ }^{57}$ which is their primary interest, alongside supporting the Prosecutor. As established in the ECCC's jurisprudence, civil participation includes 'both the right for victims to participate in the criminal trial of an accused, and to pursue a related civil action for collective and moral reparations' ${ }^{58}$ Only victims who have been granted civil party status may claim rehabilitative reparations. However, similar to the ICC, some modalities of collective reparations may potentially be enjoyed by victims who could not apply to become civil parties and, thus, were not reparations claimants at the ECCC as the Supreme Court Chamber suggested ${ }^{59}$ for example, health care services for members of an affected community. A similar approach was put forward by the civil parties' lead co-lawyers in Case 002 when discussing the implementation of collective reparations projects: 'In addition to civil parties, it could also benefit victims in a broader sense as awarding collective and moral reparations to civil parties implies that they can benefit many victims' ${ }^{60}$ Thus, some collective rehabilitative reparations could benefit a larger group than just civil parties, for example, building medical facilities or testimonial

54 ICC, Lubanga, ICC-01/04-01/06-3129) supra nt 37, para 1.

$55 \quad I d$, para 8.

56 Extraordinary Chambers in the Courts of Cambodia (ECCC), Prosecutor v Kaing Guek Eav (2009), 001/1807-2007/ECCC/TC, Case 001; Decision on Civil Party Co-Lawyers' Joint Request for a Ruling on the Standing of Civil Party Lawyers to Make Submissions on Sentencing and Directions Concerning the Questioning of the Accused, Experts and Witnesses Testifying on Character, Trial Chamber, para 33.

57 Rule 23(1)(a).

58 ECCC, Prosecutor v Kaing Guek Eav (2012), 001/18-07-2007/ECCC/TC, Case 001, Appeal Judgment, Supreme Court Chamber, para 639.

$59 \quad$ Case 001, para 659.

60 ECCC, Prosecutor v Sampah et al (2012), 002/19-09-2007/ECCC/TC, Case 002, E125/2, para 84. 
therapy of civil parties read aloud in public ceremonies with the participation of community members, survivors and relatives. ${ }^{61}$

Harm or injury relevant to reparations may be 'physical, material or psychological'. ${ }^{62}$ The injury has to be 'a direct consequence of at least one of the crimes alleged against the Charged Person' and, thus, concerning causation, the perpetrator's liability is limited to 'direct losses'. ${ }^{63}$ The Supreme Court Chamber concluded that: i) it is necessary to establish a causal link between the prohibited conduct giving rise to reparations and the form of reparations sought; ${ }^{64}$ and ii) the type of the causal link that needs to be demonstrated for the purpose of admissibility of civil party applications concerns the presence of an injury suffered as a direct consequence of the crime. The presence of the injury is conducive to the right to seek reparation. ${ }^{65}$ Further, responsibility is not limited to persons against whom crimes were perpetrated 'but may also be the direct cause of injury to a larger group of victims' ${ }^{66}$

The requirements for civil party constitution and, therefore, the possibility to claim rehabilitative reparations before the ECCC are not formal references to a specific class of individuals but instead substantive criteria of an actual injury that results as a direct consequence of the crime. ${ }^{67}$ The injury resulting from the crime charged is the defining and limiting criterion for admissibility of the civil party application before the ECCC, ${ }^{68}$ and for claiming and receiving rehabilitative reparations if the accused is convicted. To be granted (rehabilitative) reparations, the harm inflicted on victims must be directly linked to the crime(s) for which the accused was convicted. ${ }^{69}$

Based on the existence of an injury thus considered, the next question is whether not only direct but also indirect victims may be civil parties, ${ }^{70}$ and claim rehabilitative reparations to realise their right to health. The ECCC's case law has answered in the affirmative. Accordingly, indirect victims, as civil parties, can also claim rehabilitative reparations at the ECCC and receive them if the accused is convicted. Therefore, the requirement of injury as a direct consequence of the offence (rule 23bis(1)(b)) does not limit the admissibility of civil parties to direct victims and, thus, indirect victims can be included and claim rehabilitation. ${ }^{71}$

The Supreme Court Chamber has found that indirect victims are those who 'actually suffered psychological injury, for example, as a result of the injury, whether temporary or permanent, of their loved ones' ${ }^{72}$ Psychological injury is the result of uncertainty or fear

61

ECCC, Prosecutor v Sampah et al (2013) 002/19-09-2007-ECCC/TC, Case 002/01 Lead Co-Lawyers' Indication to the Trial Chamber of the Priority Projects for Implementation as Reparations, Civil Parties, para 16.

Rule 23 bis 1.

War Crimes Research Office (WCRO), SáCouto, S and Cleary, K, REPORT: The Case-Based Reparations Scheme at the International Criminal Court, June 2010, at <wcl.american.edu/warcrimes/icc/documents/report12.pdf> (accessed 17 October 2015), 38-39.

Case 001, Appeal Judgment, para 699.

Ibid.

Case 001, Judgment, para 642.

Case 001, Appeal Judgment, para 411.

Case 001, Appeal Judgment, para 415.

Case 001, Judgment, para 660.

Case 001, Appeal Judgment, para 417.

Case 001, Appeal Judgment, para 418.

Case 001, Appeal Judgment, para 417. 
about the direct victim's fate, knowledge of their suffering or loss of sense of safety and moral integrity. ${ }^{73}$ Moreover, in grave or prolonged cases, psychological injury may lead to physical injury by causing several ailments. ${ }^{74}$ Thus, the harm inflicted violates the overall right to health.

Vulnerable groups such as infants, children, the elderly and sick may have suffered psychological and physical injury as their caregivers were taken away from them. ${ }^{75}$ Indirect victims' rights, including claiming rehabilitative reparations, once constituted as civil parties, are independent of the direct victims' rights, ie, indirect victims can be granted civil party status and claim reparations even 'where the direct victim is alive and does not pursue the civil party action him or herself'. ${ }^{76}$

Questions directly related to the right to health and rehabilitative reparations under the civil party application form are: 1 . whether the applicant was examined by a doctor after the event(s) took place; 2 . whether the applicant received any medical or psychological treatment; 3. whether the applicant has any records concerning any medical or psychological treatment such as a medical report from a doctor, hospital or health centre, Xrays, prescriptions or invoices for medicines; and 4 . whether his or her condition persists to date and, if so, provision of details is needed. ${ }^{77}$ Rule $23(4)$ lays down that all civil parties' applications must inter alia 'attach evidence of the injury suffered'.

The ECCC's case law, like the IACtHR's, has considered the cultural context to examine the nature of familial relationships, particularly, extended family members ${ }^{78}$ to grant civil parties status and, therefore, expand the scope of civil parties who can claim rehabilitative reparations.

\section{Medical Rehabilitation as Reparation and Implementation}

\section{III.1. The IACtHR}

Rehabilitation as reparation has been ordered by the IACtHR to treat psychological and physical harm caused by serious human rights violations constitutive of international crimes and inflicted on victims. As previously discussed, the universe of rehabilitative reparations claimants and beneficiaries has included not only direct victims but also indirect victims such as the next of kin of executed or disappeared persons. Effective and appropriate medical and psychological treatment as well as necessary medication have normally been part of rehabilitative reparations awards. Thus, the IACtHR has granted rehabilitative reparations awards covering the cost of future medical treatment of the direct victims and also of the next of kin of deceased or executed persons. ${ }^{79}$ Free life-long access to a variety of

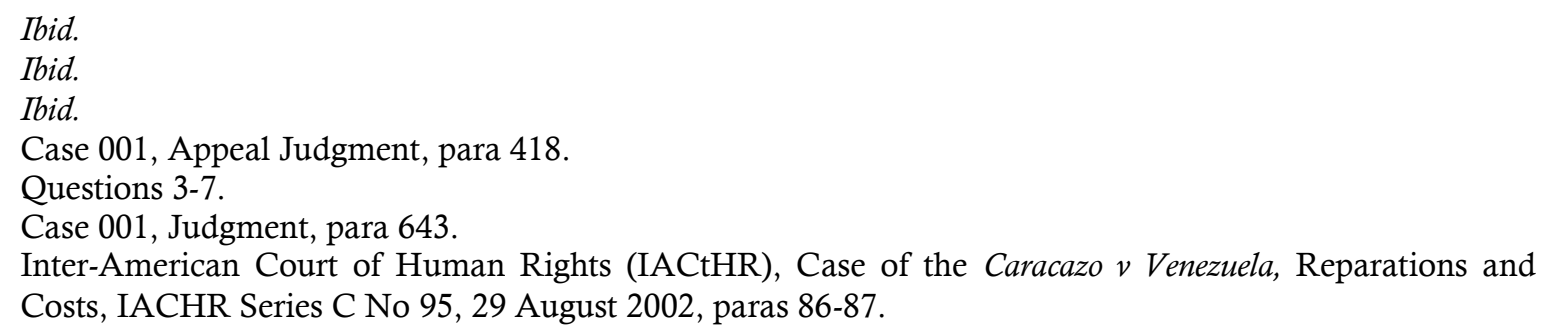


health services focused on traumatisation has also been granted and, thus, health care areas have included 'out-patient consultation, diagnostic support procedures, medicine, specialized care, diagnostic procedures, hospitalization, surgery, childbirth, traumatological rehabilitation, and mental health' ${ }^{80}$ The IACtHR has ordered the respective defendant State to afford medical and psychological care as this is found to be an appropriate form of reparations and has been given as part of individual and collective reparations awards. ${ }^{81}$

Importantly, rehabilitative reparations claimants and beneficiaries have to be consulted concerning the kind of treatment, and the respective health care needs to be free, individualised, specialised and integrated. ${ }^{82}$ Each victim's very personal needs and circumstances should be evaluated and, thus, appropriate individual, family and/or collective health care/treatment may be provided according to specific needs. ${ }^{83}$

The IACtHR has ordered States to constitute a committee to examine victims' physical and mental health and grant them treatment for a five-year period. ${ }^{84}$ The IACtHR occasionally established that victims had to request medical treatment within a specific period, for example, within two years after the IACtHR's judgment; however, the IACtHR also guaranteed its continuation as long as needed. ${ }^{85}$ Nevertheless, the IACtHR no longer requires a time limit for requesting medical treatment. This change of position is appropriate as the trauma generated on the victims may prevent them from further proceeding for some years or even 'might not manifest themselves for a period of years' ${ }^{86}$

Psychological treatment is afforded by psychologists or psychiatrists who are specialists in the specific kind of violence endured by the victims, ${ }^{87}$ and if there are no available State personnel, the State has to guarantee it via private health care. ${ }^{88}$ Treatment is generally speaking given without charge in national public facilities located near the victim's residence. ${ }^{89}$

When the harm inflicted is caused by serious human rights violations which fell short of the IACtHR's temporal jurisdiction, the IACtHR has not ordered the State to provide rehabilitation; however, it has urged the State in question to provide either rehabilitation or a monetary sum to cover rehabilitation costs and expenses. ${ }^{90}$

80 IACtHR, Case of Barrios Altos v Peru, Reparations and Costs, IACHR Series C No 87, 30 November 2001, para 42.

81 IACtHR, Case of the Plan de Sánchez Massacre v Guatemala, Reparations, IACHR Series C No 116,19 November 2004, para 107.

82 IACtHR, Case of Chitay Nech et al v Guatemala, Preliminary Objections, Merits, Reparations, and Costs, IACHR Series C No 212, 25 May 2010, para 256.

83 IACtHR, Case of the 'Las Dos Erres' Massacre v Guatemala, Preliminary Objection, Merits, Reparations and Costs, IACHR Series C No 211, 24 November 2009, para 270.

$84 \quad$ Plan de Sánchez Massacre v Guatemala, paras 106-108, 117.

85 IACtHR, Case of Kawas Fernández v Honduras, Merits, Reparations and Costs, IACHR Series C No 196, 3 April 2009.

86 Pasqualucci supra nt 20.

87 IACtHR, Case of Anzualdo-Castro v Peru, Preliminary Objection, Merits, Reparations and costs, IACHR Series C No 202, 22 September 2009, para 203.

88 IACtHR, Case of Manuel Cepeda Vargas v Colombia, Preliminary Objections, Merits, Reparations and Costs, IACHR Series C No 213, 26 May 2010, para 403.

89 IACtHR, Case of the Ituango Massacres v Colombia, Preliminary Objection, Merits, Reparations and Costs, IACHR Series C No 1481 July 2006, para 16.

90 IACtHR, Case of García Lucero et al v Chile, Monitoring Compliance with Judgment, 17 April 2015, para 37. 
In the case of serious human rights violations in which direct victims survive, for example, torture or prolonged illegal detention, the IACtHR has provided rehabilitative measures for both direct and indirect victims. Nevertheless, whereas concerning direct victims rehabilitative measures have normally consisted of both medical and psychiatric/psychological treatment, for indirect victims rehabilitative measures have been mainly limited to psychiatric/psychological treatment. ${ }^{91}$

Should the victim be a national of the defendant State but not a resident thereof, psychological and medical care are still provided in the facilities of that State, which involves return of the victim..$^{92}$ This may however be criticised considering the traumatic experiences suffered by the victim and, thus, some other alternatives should be considered. ${ }^{93}$ For example, coordination with the national health authorities of the country where the victim is resident. Another option could be provision of a monetary sum to the victim to be used for medical treatment in his or her country of residence. Be that as it may, when the victim is a migrant in relation to the defendant State, provision of a monetary sum has been afforded to enable him or her to be granted medical or psychological treatment and medication in the State of residence. Indeed, in cases where the victim lives in a State other than his or her home country, the IACtHR's practice has recently showed a predominant trend whereby medical and psychological treatment in serious human rights violations cases has been reflected as monetary sums to cover reasonable costs of that treatment in the country of residence of the victims ${ }^{94}$ In any case, victims should always be consulted on which option to follow.

Serious human rights violations constitutive of international crimes have been part and parcel of the IACtHR's case law and due to the characteristics of these atrocities, the right to health, both physical and mental, of not only an individual or a group of individuals but also of entire communities have been severely affected. Thus, the IACtHR has appropriately granted collective rehabilitative reparations to favour entire affected communities. This was the situation in Plan de Sánchez Massacre in which Mayan ethnic group members were victims of genocide. The IACtHR ordered Guatemala to provide inter alia

(c) sewage system and potable water supply [...] (e) the establishment of a health centre in the village of Plan de Sánchez with adequate personnel and conditions, as well as training for the personnel of the Rabina Municipal Health Centre so that they can provide medical and psychological care to those who have been affected and who require this kind of treatment. ${ }^{95}$

91 IACtHR, Case of Gutiérrez Soler v Colombia, Merits, Reparations and Costs, IACHR Series C No 132,12 September 2005, paras 101-103.

92 IACtHR, Case of Valle Jaramillo et al $v$ Colombia, Interpretation of the Judgment on the Merits, Reparations and Costs, 7 July 2009, para 32.

93 See also Pasqualucci supra nt 20, 203.

$94 \quad$ Gutiérrez Soler v Colombia, para 102.

$95 \quad$ Plan de Sánchez Massacre v Guatemala, para 110. 
Some of the collective rehabilitative measures, such as those detailed in the quoted paragraph, may resemble development policies or State charitable assistance. ${ }^{96}$ Accordingly, attention should be paid by the IACtHR when supervising and monitoring the implementation of reparations so that these are not politically manipulated. By doing so, the IACtHR should ensure that the provision of health care services and/or infrastructure and related services and works are afforded by the State as part of the rehabilitative reparations ordered. This is different from, albeit complementary to and linked with, the actions to be undertaken by any State to foster the development of communities.

Since the IACtHR may order a State to provide rehabilitative reparations to victims for State violations of Inter-American human rights treaties, it can monitor the State implementation of rehabilitative reparations ordered. States must inform the IACtHR about compliance with its judgments and decisions, including rehabilitative reparations awards. Under the principle of pacta sunt servanda, States abide by treaty obligations. When States proceed to fully implement rehabilitative reparations orders, they guarantee observance of the provisions and inherent effects (effet utile) within their national systems, ie, substantive and procedural norms, of the ACHR and other regional human rights treaties. The IACtHR may note non-compliance in its Annual Report. The Organization of American States (OAS) General Assembly takes no action to oblige States to comply; however, it obliges States to inform the IACtHR on compliance. Conversely, the Council of Europe Committee of Ministers supervises the implementation of the ECtHR's judgments, ${ }^{97}$ which enhances rehabilitative reparations monitoring/implementation as it puts political pressure on States. Nevertheless, an important advantage of the IACtHR's judicial monitoring of implementation of rehabilitative reparations is that it directly ensures that its awards are implemented by the State in line with the principles, contents and scheme provided for in the original reparations order. ${ }^{98}$

Since implementation of rehabilitative reparations has to be undertaken by States, there is at least in theory a sophisticated administrative State structure to implement and execute rehabilitative awards ordered by the IACtHR. ${ }^{99}$

Monitoring compliance with rehabilitative reparations orders involves the defendant State providing a report detailing whether and to what extent that State has enforced the rehabilitative measures ordered and which must be within a time limit detailed by the IACtHR in its judgment. ${ }^{100}$ Thus, the IACtHR in its powers of supervision of its judgments has established some timeframe in which the State has to nationally implement the rehabilitative reparations ordered. For instance, concerning the construction of a health centre in a village whose inhabitants were massacred, the IACtHR required the defendant State to implement this within five years of the IACtHR's merits judgment notification and to report in detail on the progressive implementation thereof to the IACtHR every year. ${ }^{101}$

\footnotetext{
96 International Centre for Transnational Justice, Lisa Magarell, REPORT: Reparations in Theory and Practice, New York, 9 January 2007, at <ictj.org/sites/default/files/ICTJ-Global-Reparations-Practice-2007English.pdf $>$ accessed at 17 October 2015, 6 .

97 ECHR, Articles 41, 46.

98 See also, McCarthy supra nt 45, 174.

99 IACtHR, Case of Serrano-Cruz Sisters v El Salvador, Merits, Reparations and Costs, IACHR Series C No 120, 1 March 2005, para 198.

100 See, Burgorgue-Larsen and Úbeda supra nt 29, 182.

$101 \quad$ Plan de Sánchez Massacre v Guatemala, para 111.
} 
Importantly, victims' participation concerning implementation of rehabilitative measures and, therefore, participation in aspects related to dimensions of their right to health is present as the IACtHR collects observations of victims or their representatives and then employs this data to effectively evaluate the level of compliance and inform the respective State of what still shall be done. ${ }^{102}$ Additionally, under the ACHR (Article 65), the IACtHR using the same information provided by the victims informs the OAS General Assembly of outstanding problems. Furthermore, an extra avenue for victims seeking to receive effective and full rehabilitation consists of holding public hearings or, depending on the circumstances, private hearings, with participation of the victims and/or their legal representatives.

An additional important question is whether this well-established procedural framework is in practice effective, ie, whether the States in accordance with the ACHR (Article 68) fully meet their obligation of observance of rehabilitative reparations ordered by the IACtHR. The fact that there are a significant number of cases being monitored is not necessarily synonymous with lack of State compliance with the IACtHR's rehabilitative reparations. ${ }^{103}$ However, States have only partially implemented rehabilitative reparations awards granted by the IACtHR. ${ }^{104}$ The uncertainty of future medical expenses in principle makes using the national health care system preferable to paying a monetary sum. ${ }^{105}$

Practice within the Latin-American region demonstrates that compliance with the IACtHR's reparations orders depends on some factors such as State willingness and capacity to do so as well as the modality of reparations. ${ }^{106}$ As for the latter, unlike compensation, which presents a high level of State compliance or symbolic measures which involve a medium level of State compliance, rehabilitative measures consisting of provision of medical or psychological health care to victims has reported a low level of compliance. ${ }^{107}$ For example, concerning the IACtHR's reparations orders against Peru, whereas compensation registered $46 \%$ full implementation, rehabilitation only reached $12 \%$ as of $2015 .{ }^{108}$ A factor that explains the low rate of implementation is the need for coordination between the national ministries of health and the local bureaucracies who run the local health care services and centres. ${ }^{109}$

The timeframe for full implementation of rehabilitative reparations may substantially vary from country to country and from judgment to judgment. On some occasions, delay in implementation of rehabilitative measures has led to serious consequences for the right to health of the victims. For example, in Sawhoyamaxa Indigenous Community, notwithstanding the IACtHR's reparations award, Paraguay did not provide the members of the indigenous

102 See Burgorgue-Larsen and Úbeda supra nt 29, 182.

103 Pasqualucci supra nt 20, 305.

104 Ibid.

$105 \quad I d, 314$.

106 Burgorgue-Larsen and Úbeda supra nt 29, 183.

107 Pasqualucci supra nt 20, 305-306; Beristain, CM, Diálogos sobre la reparación: Experiencias en el sistema interamericano de derechos humanos(Instituto Interamericano de Derechos Humanos, Costa Rica, 2008) 548.

108 Instituto de Democracia y Derechos Humanos-Universidad Católica del Perú (IDEHPUCP), Bulletin on Implementation of Reparations by the Inter-American Court (15 August 2015), at <idehpucp.pucp.edu.pe/wp-content/uploads/2013/07/Bolet\%C3\%ADn-Per\%C3\%BA-2015.pdf> (accessed 5 December 2015).

109 Pasqualucci supra nt 20, 314. 
community with health care, food and water and, thus, they became incapable of continuing to live on their ancestral lands. ${ }^{110}$ As a consequence, four vulnerable persons, including three children, perished, for which the IACtHR severely criticised Paraguay. ${ }^{111}$ Although the IACtHR issued injunction orders in subsequent compliance orders, other community members' health deteriorated to the point that a number of them also died. ${ }^{112}$ This difficult situation prompted the IACtHR's President to call a public hearing so that Paraguay could present an explanation of the events. This was an extreme example of a trend which seemingly and often indicates incomplete compliance with rehabilitative reparations. ${ }^{113}$

Sometimes State efforts proved to be insufficient. Colombia failed to implement the IACtHR's orders to afford free medical and psychological treatment via the national health system. In Vargas Areco, the hospital in which the victim was enrolled was hundreds of kilometres away from his home. ${ }^{114}$ In Cantoral Benavides, Peru's efforts were insufficient as the victim had to wait for several hours each session due to the required registration and was not immediately provided medication. ${ }^{115}$ In Juvenile Reeducation Institute, only 43 victims out of thousands of potential beneficiaries were registered to receive medical attention. ${ }^{116}$

The enforcement of rehabilitative reparations awards is continuously monitored until the IACtHR considers that they have been fulfilled and, thus, constitutes one of the IACtHR's most demanding activities. ${ }^{117}$

\section{III.2. The ICC}

Under Article 75 of the ICC Statute and related ICC RPE, reparations, including rehabilitation, can be individual or collective. Although individual awards in principle seem to be of a monetary nature, individual victims can also claim rehabilitation and other forms of remedy. Indeed, victims in Lubanga considered not only compensation as part of individual awards. ${ }^{118}$ When collective reparations awards are granted, 'these should address the harm the victims suffered on an individual and collective basis' ${ }^{119}$ Furthermore, the Trial Chamber considered that the ICC should provide medical services (psychiatric and

110 IACtHR, Case of the Sawhoyamaxa Indigenous Community v Paraguay, Merits, Reparations and Costs, IACHR Series C No 146,29 March 2006; See also Burgorgue-Larsen and Úbeda supra nt 29, 183.

111 IACtHR, Case of the Sawhoyamaxa Indigenous Community v Paraguay, Monitoring Compliance with Judgments, Order of the President,recitals 11, 12 .

$112 \quad I d, 37$.

113 Burgorgue-Larsen and Úbeda supra nt 29, 183; IACtHR, Annual Report 2008, OEA/Ser.L/V/II.134, Doc. 5, rev. 1, 25 February 2009, at <cidh.org/annualrep/2008eng/TOC.htm> (accessed 17 October 2015), 75; Cavallaro, J, and Breyer, S, "Reevaluating regional human rights litigation in the twenty-first century: the case of the Inter-American Court", 102 American Journal of International Law (2008), 768-827.

114 IACtHR, Case of Vargas Areco v Paraguay, Monitoring Compliance, Order of the IACtHR, 24 November 2010, para 19.

115 IACtHR, Case of Cantoral Benavides v Peru, Monitoring Compliance, Order of the IACtHR, 14 November 2010, para 14.

116 IACtHR, Case of the 'Juvenile Reeducation Institute'v Paraguay, Monitoring Compliance, Order of the IACtHR, 19 November 2009, paras 18, 19, 24.

117 IACtHR, Annual Report 2011, OEA/Ser.L/V/II., Doc. 69, 30 December 2011, at <oas.org/en/iachr/docs/annual/2011/toc.asp> (accessed 17 October 2015), 19.

118 Lubanga (ICC-01/04-01/06-2869), 18 April 2012, paras 16 and 20.

$119 \quad I d$, para 221. 
psychological care included), in addition to assistance on rehabilitation, housing, education and training. ${ }^{120}$ Collective awards can also be made up of restitution, rehabilitation or other remedies awarded to a group of victims. ${ }^{121}$ Article $75(2)$ lists the modalities of restitution, compensation and rehabilitation. However, this enumeration is only illustrative and not exhaustive since the word 'including' is used and is interpreted by Trial Chamber I. ${ }^{122}$ Besides a gender-sensitive approach, other reparations modalities with symbolic, preventive or transformative value are appropriate. ${ }^{123}$ Reparations modalities, including rehabilitation, identified and discussed by Trial Chamber I were consistent with those asked/suggested by the victims, ${ }^{124}$ the OPCV,${ }^{125}$ and the TFV. ${ }^{126}$

Reparations in the form of assistance or rehabilitation programmes, as individual or collective awards, may be better than compensation, especially when the amount of payment is nominal. ${ }^{127}$ The TFV has indeed considered that compensation, as a modality of reparation, may be less suitable than rehabilitation. ${ }^{128}$ However, it is herein argued that a reparations programme should usually, and when feasible, include measures integrating monetary, rehabilitative and symbolic components rather than relying exclusively on or excluding a modality of reparations altogether. ${ }^{129}$ The UN Basic Principles and Guidelines refer to 'adequate, appropriate and prompt reparation' ${ }^{130}$ which indicates the need for some appropriate combination of medical and psychological rehabilitation with other forms of reparations. ${ }^{131}$

Trial Chamber I, relying on, inter alia, the IACtHR's case law and UN Basic Principles and Guidelines, found rehabilitation to include: 1. the provision of medical services and health care, in particular treatment of HIV and AIDS; 2. psychological, psychiatric and social assistance to support victims enduring grief and trauma; and 3. any relevant legal and social services. ${ }^{132}$ Rehabilitation has to be implemented by the ICC in correspondence with the non-discrimination principle, which includes a gender inclusive approach encompassing males and females of all ages. ${ }^{133}$ Rehabilitation steps may also include communities of victims to the extent that rehabilitative reparations programmes are implemented where their communities are located. ${ }^{134}$ Programmes with transformative objectives, regardless of how

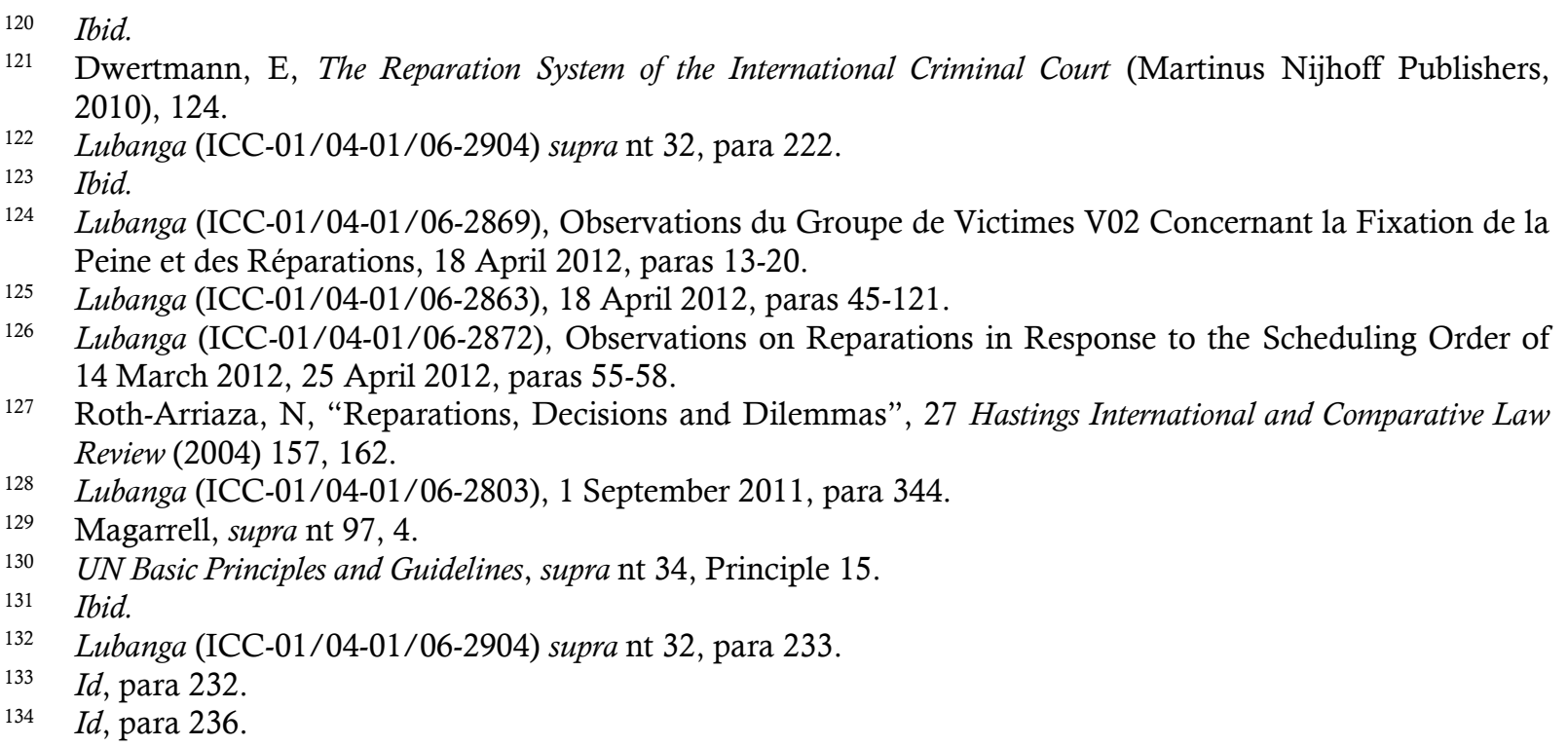


limited they may be, can actually help to prevent future victimisation and symbolic measures, such as commemorations and tributes, may also contribute to rehabilitation. ${ }^{135}$ As for vulnerable groups of victims, for example, former child soldiers, rehabilitation should include measures directed at facilitating their reintegration to society, bearing in mind the differences in the impact of those crimes on boys and girls. ${ }^{136}$ Indeed, as the Trial Chamber recognised, priority may be afforded to vulnerable victims including severely traumatised children, sexual/gender-based violence victims and to those who require medical care, particularly when plastic surgery or HIV treatment is needed. ${ }^{137}$

Rehabilitative measures should include manners of addressing the shame that victims may feel and, indeed, they 'should be directed at avoiding further victimisation of the boys and girls who suffered harm as a consequence of their recruitment [as child soldiers]'. ${ }^{138}$ Trial Chamber I considered collective rehabilitative measures, including child soldiers' communities, in steps taken to rehabilitate and re-integrate child soldiers, as those programmes are implemented in the respective communities. ${ }^{139}$ Moreover, as for children beneficiaries of rehabilitative reparations, the principle of the 'best interests of the child' embedded in the Convention on the Rights of the Child should inter alia guide the ICC's decisions. ${ }^{140}$ Furthermore, reparations proceedings, orders and programmes that benefit child soldiers should guarantee the development of the victims' personalities, help them obtain rehabilitation and reintegrate them into society. ${ }^{141}$

Concerning implementation of rehabilitative reparations such as medical, social and psychological rehabilitation, these require a considerable amount of money to be funded. Thus, it is not quite realistic to assume that the convicted individual or individuals can finance them, let alone the fact that the States are expected to provide social security or health care services. ${ }^{142}$

Regarding implementation of rehabilitative reparations at the ICC, the TFV is a key institution as it serves for the 'benefit of victims of crimes within the jurisdiction of the Court, and of the families of such victims'. ${ }^{143}$ The TFV's mandate is twofold and reflects its relationship with the ICC. Its first mandate is to ensure the existence of sufficient available funds in case the ICC orders reparations in accordance with Article 75(2) of the ICC Statute, ${ }^{144}$ which provides that 'where appropriate, the Court may order that the award for reparations be made through the Trust Fund provided for in Article 79'. This has been the

\section{Ibid.}

Id, para 234.

$I d$, para 200.

Id, para 235.

Id, paras 236-240.

140 Article 3, United Nations, Convention on the Rights of the Child (1990) 1; Lubanga (ICC-01/04-01/06-2904) supra nt 32 , para 210.

141 Lubanga (ICC-01/04-01/06-2904) supra nt 32, paras 213 and 216.

142 Dwertmann, supra nt 122, 148-149.

143 ICC Statute, article 79(1).

144 Situation in the DRC (ICC-01/04-492), Decision on the Notification of the Board of Directors of the Trust Fund for Victims in accordance with Regulation 50 of the Regulations of the Trust Fund, 11 April 2008, 7. 
case in Lubanga, as detailed by the A.Ch. ${ }^{145}$ This 'reparations mandate' is linked to specific ICC cases. ${ }^{146}$ Under this mandate, the TFV implements reparations awards for victims ordered by the Court against the convicted in accordance with ICC's specific criteria. The TFV's second function, ie, the general assistance function, ${ }^{147}$ is of a non-judicial or humanitarian nature. ${ }^{148}$ Under the TFV's case-based reparations mandate, the ICC can direct the TFV to use resources deposited with it to implement ICC-ordered reparations against a convicted person. Conversely, under its general assistance mandate, the TFV may use voluntary contributions to provide general assistance, ie, technically-speaking not reparations, to all victims of the ICC situations.

The TFV has gathered experience with rehabilitation programmes implemented under its assistance mandate, highlighting this as important know-how when implementing similar initiatives concerning reparations orders. ${ }^{149}$ Accordingly, an option is to implement and finance similar rehabilitation programmes under the TFV's management for case-based reparations claimants and beneficiaries. A second alternative is to incorporate reparations beneficiaries to programmes already run by the TFV for victims of situations in general, while always making it clear that the former category of victims are reparations beneficiaries and not general assistance beneficiaries. If the convicted is found to have funds, she or he can be ordered to at least partially finance the rehabilitation of victims or a rehabilitative programme as part of a collective reparations award. ${ }^{150}$

The exact scope of beneficiaries of rehabilitative measures, ie, total identification of eligible individual beneficiaries, in Lubanga is yet to be determined via the implementation of TFV's reparations plan under the ICC Trial Chamber's monitoring and oversight. Not restricting the universe of potential claimants and beneficiaries of rehabilitation to only those who are/were victim participants also corresponds to minimum considerations of nondiscrimination, as 'it would be inappropriate to limit reparations to the relatively small group of victims that participated in the trial and those who applied for reparations' ${ }^{151}$ Considering factors such as on-going armed violence, remoteness and intimidation that may have prevented victims from participating during the trial, this is also a realistic approach. Accordingly, victims, as defined in Rule 85, have to be given equal access to any information relating to their right to rehabilitative reparations and the ICC's assistance, ${ }^{152}$ which is also in line with the UN Basic Principles and Guidelines. ${ }^{153}$ Concerning those who lost their victim participant status due to problems with their testimonies in Lubanga, they

145 Lubanga (ICC-01/04-01/06-2953), Decision on the Admissibility of the Appeals Against Trial Chamber I's "Decision Establishing the Principles and Procedures to be Applied to Reparations" and Directions on the Further Conduct of Proceedings, Appeals Chamber, 14 December 2012, para 55.

146 ICC Assembly of State Parties, Report to the Assembly of States Parties on the Activities and Projects of the Board of Directors of the Trust Fund for Victims for the Period 1 July 2011 to 30 June 2012, ICC-ASP/10/14, 7 August 2012, paras 3-8.

147 Id, paras 9-13.

148 Zegveld, supra nt 7, 88.

149 Lubanga (ICC-01/04-01/06-2803), Trust Fund for Victims' First Report on Reparations, 1 September 2011, paras 319-326.

150 Dwertmann, supra nt 122, 149.

151 Lubanga (ICC-01/04-01/06-2904) supra nt 32, para 187.

$152 \quad$, Id, para 188.

153 UN Basic Principles and Guidelines, supra nt 34, Principles 11, 12 and 24. 
may still claim and benefit from rehabilitative reparations if the respective causal link is proved, as noted by the A.Ch. ${ }^{154}$

As previously said, the ICC cannot issue rehabilitative reparations against the States Parties to the ICC Statute. However, concerning enforcement of those orders, the ICC can oblige the States Parties to conduct certain measures as they are required to cooperate with the ICC. ${ }^{155}$ Article 75(4) of the ICC Statute states that the ICC 'may [...] determine whether, in order to give effect to a [reparations] order which it may make under this article, it is necessary to seek measures under article 93 [Other forms of cooperation]'. The ICC motu proprio, the Prosecutor or victims who claimed/will claim rehabilitative reparations via application may request State cooperation. ${ }^{156}$ Seizure of assets may be used to enforce reparations orders. ${ }^{157}$ Article 75(5) states that the enforcement regime for fines and forfeiture order (Article 109) shall apply to the ICC's reparations orders and States Parties shall fully enforce ICC rehabilitative reparations orders. In enforcing these orders, national authorities cannot modify them. ${ }^{158}$ This is related to the dependence of the ICC's efficacy on State cooperation.

Under its general assistance mandate, the TFV may consider it necessary to provide physical or psychological rehabilitation [...] for the benefit of victims and their families'. ${ }^{159}$ Thus, the TFV notified the ICC of its plans to conduct assessments of needs as part of specific projects to provide physical, psychological and material support to victims in two ICC country situations: Uganda and the Democratic Republic of Congo (DRC). The TFV Board of Directors estimated that those projects would benefit more than 380,000 victims, ${ }^{160}$ and similar projects in the Central African Republic (CAR) were prepared, ${ }^{161}$ and approved. ${ }^{162}$ Those estimations should be taken carefully since the notion of beneficiaries 'is probably being used rather loosely'. ${ }^{163}$ Nonetheless, the nature and scale of projects handled by the TFV show the great potential that such institutions have to bring restorative justice via rehabilitative reparations to a much larger number of victims in contexts involving thousands or millions of victims. Among others, the TFV has set out the following categories of programmes directly related to the right to health and consistent with rehabilitative measures.

154 Lubanga (ICC-01/04-01/06-2953), 14 December 2012, para 70.

155 ICC Statute, Part 9 (International Cooperation and Judicial Assistance), particularly, Articles 93 and 109. See also Articles 86 and 88.

156 Schabas, W, The International Criminal Court. A Commentary on the Rome Statute (Oxford University Press, 2010), 883.

157 RPE, Rule 99.

158 RPE, Rule 219.

159 TFV Regulation 56.

160 ICC Assembly of State Parties, Report to the Assembly of States Parties on the Activities and Projects of the Board of Directors of the Trust Fund for Victims for the period 1 July 2007 to 30 June 2008, ICC-ASP/7/13, 3 September 2008, para 22.

161 ICC Assembly of State Parties, Report to the Assembly of States Parties on the projects and the activities of the Board of Directors of the Trust Fund for Victims for the period 1 July 2011 to 30 June 2012, ICC-ASP/11/14, 7 August 2012, 1.

162 Situation in the CAR (ICC-01/05-41), Decision on the 'Notification by the Board of Directors in Accordance with Regulation 50 a) of the Regulations of the Trust Fund for Victims to Undertake Activities in the Central African Republic', Pre-Trial Chamber II, 23 October 2012.

163 Schabas, supra nt 156, 915. 
Physical rehabilitation, which includes reconstructive surgery, general surgery, bullet and bomb fragment removal, prosthetic and orthopedic devices, referrals to services such as fistula repair and HIV and AIDS screening, treatment, care and support;

Psychosocial rehabilitation, which includes both individual and group-based trauma counselling [...]. ${ }^{164}$

Implementing special initiatives for children born out of rape and children who themselves have been victimized by sexual and gender-based crimes [...] including access to basic services $[\ldots]$ nutrition support $[\ldots] .{ }^{165}$

The target beneficiaries/victims have been categorised in groups including: 1 . children and youth; 2 . victims of physical trauma; 3 . other war victims; 4 . community peace builders; v) former child soldiers; ${ }^{166}$ and 5 . victims of sexual and gender-based violence. ${ }^{167}$ Most beneficiaries/victims receive a combination of integrated physical and psychological rehabilitation and/or material support. ${ }^{168}$

As to the kind of support provided by the TFV in pursuit of its general assistance mandate outside case-based reparations, the provision of resources does not amount to 'reparations' as it belongs to a separate, broader mandate which covers the 'provision of assistance of victims in general'. ${ }^{169}$ Support outside a case litigated before the ICC does not qualify as rehabilitative reparations under the ICC reparations scheme. ${ }^{170}$ However, it is argued herein that such assistance redresses harm of victims of crimes relating to the ICC situations since any support by the TFV 'must seek to redress the harm victims have suffered as a result of the crime to which they or their loved ones were subjected'. ${ }^{171}$ The TFV rehabilitative programmes implemented under its general assistance mandate are mutatis mutandis similar to rehabilitative reparations. Indeed, Trial Chamber I acknowledged the importance of the TFV's general assistance programmes involving '[...] child soldiers rehabilitation, sustained by the TFV, which provide support to former child soldiers'. ${ }^{172}$ Accordingly, the TFV's rehabilitation initiatives under its assistance and case-based reparations mandates attempt to redress the damage caused to the victims' right to health.

In any case, transferring funds from the TFV's general assistance mandate to case-based rehabilitative reparations falls within the sole discretion of TFV's Board of Directors and, thus, when the accused is indigent, the TFV may advance its 'other resources'. ${ }^{173}$ This intervention does not exonerate the convicted from liability and he or she is expected to

164 ICC Assembly of State Parties, Report to the Assembly of States Parties on the activities and projects of the Board of Directors of the Trust Fund for Victims for the period 1 July 2009 to 30 June 2010, 28 July 2010, ICC-ASP/9/2, 28 July 2010, para 4.

165 ICC-ASP/11/14, 7 August 2012, para 10.

166 ICC-ASP/7/13, 3 September 2008, para 9.

167 ICC-ASP/11/14, 7 August 2012, para 10.

168 ICC-ASP/7/13, 3 September 2008, para 10.

169 ICC-ASP/7/13, 3 September 2008, paras 15-17.

170 McCarthy, C, "Reparations under the Rome Statute of the International Criminal Court and Reparative Justice Theory", 3 International Journal of Transitional Justice (2009) 250, 269.

171 Ibid.

172 Lubanga (ICC-01/04-01/06-2904) supra nt 32, para 275.

173 Lubanga (ICC-01/04-01/06-3129) supra nt 37, para 4. 
reimburse the TFV. ${ }^{174}$ This has been the proceeding followed in Lubanga and, thus, timely and adequate rehabilitative reparations can be provided to the victims.

It is expected and advisable that TFV allocates part of its general assistance mandate funds to complete, if needed, the necessary funds to enforce rehabilitative reparations awards and/or, as previously suggested, to allow rehabilitative reparations beneficiaries to benefit from its assistance mandate rehabilitative measures to get their harm redressed. The TFV approved EUR 1.9 million for its assistance mandate projects and EUR 3.6 million for its reparations preparation reserve. ${ }^{175}$ In any case, the two TFV's mandates should work closely to maximise victims' rehabilitation and also reduce the fragmentation of the victims' universe, avoiding tension among victims, as much as possible.

\section{III.3. The ECCC}

Modalities of reparations at the ECCC mainly fall under the categories of satisfaction and rehabilitation following the UN Basic Principles and Guidelines. Rule 23(2) explicitly lays down that ' $[\mathrm{t}]$ he right to take civil action may be exercised without any distinction based on criteria such a current residence or nationality'. This rule is particularly important as it specifically implements the principle of non-discrimination. By making it explicit that the reparations regime, including rehabilitation, under the ECCC is led by the principle of nondiscrimination, the ECCC Internal Rules drafters reached a standard coherent with the UN Basic Principles and Guidelines. ${ }^{176}$

Unlike the ECCC's current reparations regime in which an external funding/implementing mechanism is feasible, under the ECCC's original regime, reparations could only be funded by the convicted. Thus, requests for the provision of access to free medical care were rejected by the Trial Chamber in Case 001 as, by their nature, they were designed to benefit a large number of individual victims and, thus, those reparations requests were outside available reparations at the ECCC's previous reparations regime. ${ }^{177}$ When appealing this decision, civil party group 2 argued, inter alia, that the Trial Chamber misunderstood its claim as they only requested treatment for 17 people and not for a larger number of individual victims. ${ }^{178}$ The Supreme Court Chamber emphasised the requirement of a causal link between the reparation measures sought by each civil party appellant and the injury caused by the crimes for which the accused was convicted. ${ }^{179}$ The Chamber found the provision of physical and/or psychological treatment of the injury to be a suitable modality of reparations since the injury inflicted on the victims is the damage to their physical and/or psychological health. ${ }^{180}$ The Chamber then examined whether the reparations measure

$174 \quad I d$, para 5.

175 ICC Assembly of State Parties, Report to the Assembly of States Parties on the Activities and Projects of the Board of Directors of the Trust Fund for Victims for the Period 1 July 2013 to 30 June 2014, ICC-ASP/12/14, 31 July 2013, 1-2.

176 UN Principles and Guidelines, supra nt 34 Principles 12 and 25.

177 Case 001, Judgment, 26 July 2010, para 674.

178 Case 001, Appeal against Judgment on Reparations by Co-Lawyers for Civil Parties - Group 2, 2 November 2010, para 90.

179 Case 001, Appeal Judgment, 3 February 2012, para 699.

180 Ibid. 
request qualified as 'collective and moral'. ${ }^{181}$ Relying on the IACtHR's jurisprudence, the Supreme Court Chamber concluded that the provision of medical and psychological care is an appropriate form of reparations and that it falls under the term 'collective and moral' reparations under the Internal Rules. ${ }^{182}$ Rehabilitation is especially suitable when it is not possible for the competent court to identify the totality of victims, ie, the totality of all rehabilitative reparations beneficiaries and, thus, to order rehabilitative measures, alongside other modalities of reparations, rather than provide individual compensation. ${ }^{183}$

The last analytical step of the Supreme Court Chamber was 'enforceability' of the rehabilitative reparations sought. ${ }^{184}$ Unlike the IACtHR's case law, where there is normally a sophisticated administrative structure to be implemented and executed by the State, the ECCC 'is not vested with powers to render binding orders against the Cambodian State [...]'. ${ }^{185}$ Nor did the ECCC have an explicit State's proposal in Case 001 to be able to assist a potentially large, undefined category of beneficiaries, ${ }^{186}$ unlike the IACtHR's practice. ${ }^{187}$ These previous considerations must be read '[i]n the context of the ECCC [where] orders can only be borne by convicted persons' ${ }^{188}$ under the previous reparations implementation regime. The Supreme Court Chamber concluded that although the provision of medical care constitutes in general an appropriate modality of reparations, the reparations request is not maturate enough to be singled out for the Chamber's individual endorsement due to the lack of, inter alia, information on the estimated cost of the rehabilitative reparations, number and identities of beneficiaries and duration and modality of the treatments needed. ${ }^{189}$

Like the ECCC's original regime, ${ }^{190}$ when the reparations awards under the new regime are ordered by the Chamber to be borne by the accused, ${ }^{191}$ the ECCC lacks competence to enforce reparations awards and, accordingly, they can only be enforced, where necessary, within the ordinary Cambodian court system pursuant to, and satisfying, enforcement requirements under Cambodian domestic law - including with regard to specificity. ${ }^{192}$

However, the crucial difference is that, unlike the original reparations implementation regime, reparations awards, including rehabilitation, cannot only be borne by the accused under the current regime. A decisive factor to reject collective rehabilitative reparations requested by civil parties in Case 001 was (almost) insurmountable obstacles for their implementation - due to the ECCC framework and the convicted's indigence - although rehabilitative proposals were, in principle, considered appropriate by the Supreme Court Chamber. Nevertheless, the regime of implementation of reparations awards at the ECCC was amended on 17 September 2010 and is applicable to Case 002. Internal Rule 23quinquies(3)(b) lays down that

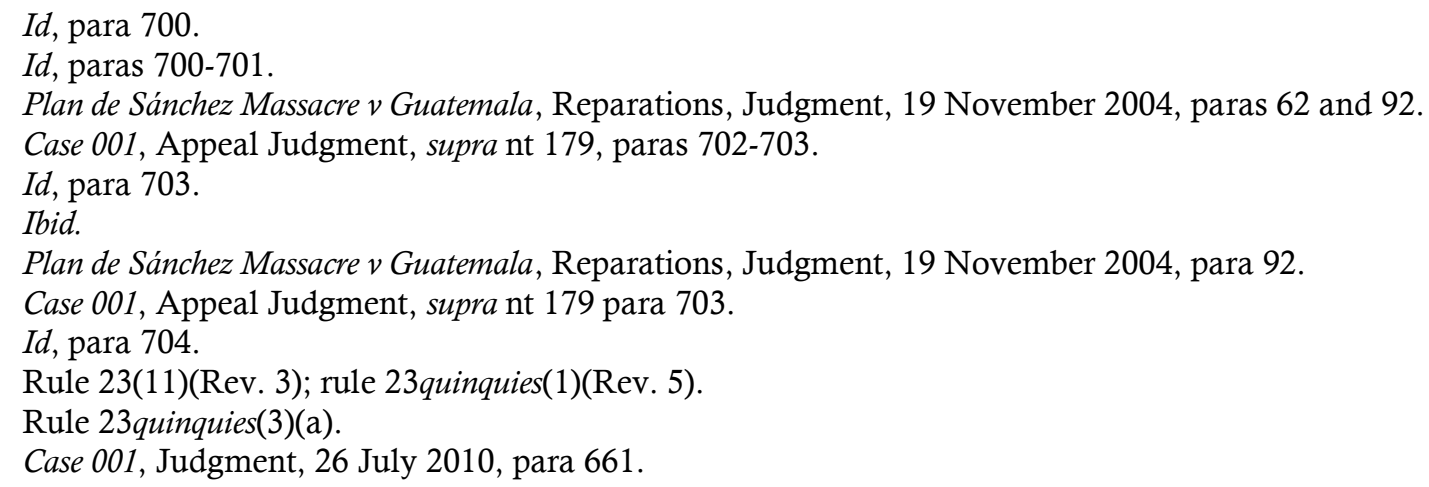


3. In deciding the modes of implementation of the awards, the Chamber may, in respect of each award, either:

a) order that the costs of the award shall be borne by the convicted person; or

b) recognise that a specific project appropriately gives effect to the award sought by the Lead CoLawyers and may be implemented. Such project shall have been designed or identified in cooperation with the Victims Support Section and have secured sufficient external funding. ${ }^{193}$

The VSS may, in liaison with an external entity, (having secured funding) implement reparations awards, as established under internal Rule 12bis(2): 'The Victims Support Section shall, in co-operation with the Lead Co-Lawyers and, where appropriate, in liaison with governmental and non-governmental organisations, endeavour to identify, design and later implement projects envisaged by Rule 23quinquies(3)(b)'.

The Supreme Court Chamber in Case 001, concerning the request for provision of medical treatment and psychological services for civil parties, remarked that a workable solution (for Case 002 and other ongoing or future cases) may be setting up an externally-subsidised trust fund whose administrative structure would be tasked with the implementation of measures asked. ${ }^{194}$ As the Chamber appropriately highlighted, ${ }^{195}$ the amendments to the Internal Rules established that the ECCC may recognise reparations projects designed and identified by the civil parties' lead co-lawyers in cooperation with the VSS under internal Rule 23quinquies(3)(b). Although the Supreme Court Chamber welcomed this new innovative regime, the Chamber noted that it was inapplicable in Case 001. ${ }^{196}$ Thus, it found that the Trial Chamber in Case 001 correctly dismissed the request to establish a trust fund. ${ }^{197}$ Accordingly, the Supreme Court Chamber merely encouraged the civil parties in Case 001, many of whom are also civil parties in Case 002, and to which case internal Rule 23quinquies(3)(b) applies, to seek, for example, the provision of access to free medical care via the amended system. ${ }^{198}$

In applying the new reparations implementation regime, the civil parties' lead co-lawyers, in collaboration with the VSS, analysed the requests from the 11 legal teams representing civil parties in Case 002 and identified four main categories of projects to be implemented. ${ }^{199}$ The second category was rehabilitation and consisted of a range of awards aiming to restore the victims' mental and physical health, or at least mitigate their harm, ie projects to establish psychological and physical health services and to support a self-help group. ${ }^{200} \mathrm{In}$ Case 002/01, upon the Trial Chamber's request, the civil parties' lead co-lawyers submitted a prioritised list of reparations projects. To endorse the reparations projects, the Trial Chamber set the following requirements:

193 Emphasis added.

194 Case 001, Appeal Judgment, 3 February 2012, 315, footnote 1430.

195 Ibid.

196 Ibid.

197 Case 001, Judgment, 26 July 2010, para 670.

198 Case 001, Appeal Judgment, supra nt 179, 315, footnote 1430.

199 ECCC, Case 002, Initial Specification of Substance of the Awards that the Civil Party Lead Co-Lawyers Intend to Seek filed on 12 March 2012 by the Civil Party Lead Co-Lawyers, E125/2 (Awards Sought by Civil Party Lead Co-Lawyers) in para 55.

200 ECCC, Case 002, Awards Sought by Civil Party Lead Co-Lawyers, 12 March 2012, paras 66-69. 
1) Proof of consent and cooperation of any involved third party has to be demonstrated;

2) Funding has to be fully secured, as the Chamber cannot endorse a reparation project that has secured partial funding only;

3) Any necessary additional information shall be provided to the Chamber, such as detailed descriptions [...] and budget plans of proposals. ${ }^{201}$

The second category (rehabilitation) in turn consisted of two projects. First, testimonial therapy, which aimed to provide civil parties in Case 002/01 the means to address the psychological suffering caused by the crimes perpetrated against them by talking [about] and recording the traumatic experiences with mental health workers'. Such testimonials 'would later be read aloud in public ceremonies in accordance with religious or spiritual beliefs and cultural practices'. ${ }^{202}$ It had received partial funding (from Germany) but the Trial Chamber requested clarification of whether that funding would be sufficient to cover the 36 months to implement the project planned in conjunction with the Transcultural Psychological Organization Cambodia, a non-governmental organisation active in the mental health area in Cambodia, or, in case of no further funding, for how long the project could continue. ${ }^{203}$ Second, self-help groups, which would provide the civil parties in Case 002/01 'with collective therapy through participation in eight group sessions, permitting them to talk about their suffering ${ }^{204}$, and about which the same situation/observations concerning the previous project were applicable. ${ }^{205}$

Civil parties finally managed to secure funding from Australia, Germany and Switzerland for the testimonial therapy in both projects, the second of which to be provided via therapy developed by the Transcultural Psychosocial Organization. ${ }^{206}$ Civil parties' lawyers also expressed that they were seeking funds to expand the rehabilitative projects outside Phnom Penh. Considering the funds obtained, the Trial Chamber endorsed the rehabilitative reparations projects and authorised their expansion provided that, in the latter case, funds are secured. ${ }^{207}$

With regard to whether the ECCC can issue rehabilitative reparations orders, the enforcement of which may require governmental administrative assistance, the Supreme Court Chamber stressed that it lacks jurisdiction over matters that are not statutorily conferred on it and, thus, reiterated its absence of a mandate and jurisdiction over Cambodia or its Government to compel it to administer a reparations scheme. ${ }^{208}$ The Government cannot be engaged by the ECCC as a civil defendant, nor can the ECCC exercise jurisdiction

201 ECCC, Case 002/01, Trial Chamber's Subsequent and Final Order on the Updated Specification of Civil Party Priority Projects as Reparations (Trial Chamber's Subsequent and Final Order), E218/7/4, 6 September 2013, para 3.

202 ECCC, Case 002/01, Trial Chamber's Response to the Lead Co-Lawyers' Initial Specification of Civil Party Priority Projects as Reparations (Trial Chamber's Response), 1 August 2013, E218/7/2, para 3.

203 ECCC, Case 002/01, Trial Chamber's Subsequent and Final Order, 6 September 2013, para 5.

204 ECCC, Case 002/01, Trial Chamber's Response, supra nt 202, para 3.

205 ECCC, Case 002/01, Trial Chamber's Subsequent and Final Order, supra nt 203, para 5.

206 ECCC, Case 002/01, Judgment (Trial Chamber), 7 August 2014, paras 1131-1133.

$207 \quad I d$, paras 1154-1155.

208 ECCC, Case 001, Appeal Judgment, supra nt 179, para 663. 
such as encroachment of statutory competence over the Executive. ${ }^{209}$ Accordingly, the Supreme Court Chamber concluded that

any reparation claim is predestined for rejection that necessarily requires the intervention of [...] [Cambodia] to the extent that, in effect, such request predominantly seeks a measure falling within governmental prerogatives. This is the case, for instance, with respect to requests for [...] organization of health care. ${ }^{210}$

However, the Supreme Court Chamber also concluded that domestic courts are bound to give effect to ECCC reparations orders against convicted persons, similar to any other reparations order delivered by Cambodian domestic courts. ${ }^{211}$

\section{Rehabilitative Reparations and International Human Rights Law, Particularly, the Obligation to Cooperate and the Right to Health Standards/Principles}

In the previous sections, substantive and procedural law on medical rehabilitation as reparation at the IACtHR, ICC and ECCC has been exhaustively examined. A crucial factor in the success of implementation of rehabilitative reparations awards and the related realisation of the right to health is funding. Whereas rehabilitative reparations awards ordered by the IACtHR must be financed by the respective State found internationally responsible, rehabilitative reparations awards ordered by the ICC and ECCC cannot be addressed to States. There is certainly an obligation for the States Parties to the ICC Statute to cooperate with the ICC but not a direct obligation to fund the ICC rehabilitative reparations awards or the rehabilitative humanitarian programmes implemented by the TFV. At the ECCC, the situation is even more precarious due to its much narrower scope. Even medical rehabilitative reparations awards rendered by the IACtHR, ordering, for example, construction of hospitals, have found no few difficulties to be implemented because of the lack of economic/technical resources across Latin-American countries. These difficulties are clear obstacles to the realisation of the right of health of victims as rehabilitative reparations claimants.

In this section, it is first argued that States, particularly developed ones, should contribute to implementing medical rehabilitation reparations. This lies in the fact that these reparations measures realise the victims' right to health and developed States have an obligation to cooperate to fulfil such a right. Secondly, rehabilitative reparations are considered in light of the right to health standards and principles established by the UN Committee on Economic, Social and Cultural Rights (CESCR).

Article 2(1) of the International Covenant on Economic, Social and Cultural Rights (ICESCR) establishes binding legal obligations of international assistance and cooperation upon its States Parties, which must 'take steps, individually and through international

$\begin{array}{ll}209 & \text { Ibid. } \\ 210 & I d, \text { para } 664 . \\ 211 & I d, \text { para } 665 .\end{array}$ 
assistance and co-operation, especially economic and technical, to the maximum of [their] available resources, with a view to achieving progressively the full realization of the rights recognized in the present Covenant by all appropriate means'. In turn, Article 22 provides that the Economic and Social Council may bring to the UN bodies and agencies competent to furnish technical assistance any information out of the State reports under the ICESCR which 'may assist such bodies [...] on the advisability of international measures likely to contribute to the effective progressive implementation of the present Covenant'. Article 23 mentions several forms of international action to fulfil the ICESCR, ie the right to health (ICESCR, Article 12), including 'the furnishing of technical assistance'. ${ }^{212}$

Thus, the obligations of international assistance and cooperation would arguably demand the States Parties to the ICESCR, particularly those most affluent, to contribute funding to rehabilitative reparations ordered by the ICC, ECCC and IACtHR and/or provide technical assistance to meet some of their obligations to ensure the right to health and/or to help developing States meet those obligations. Obligations under the right to health require States to undertake actions not only concerning individuals under their jurisdiction but also beyond. Indeed, there is an increasing trend consisting of the State obligation to protect human rights beyond its national territory, as recognised by both scholars ${ }^{213}$ and the CESCR. ${ }^{214}$ Accordingly, the ICESCR States Parties' obligations to adopt measures to the maximum of their available resources include not only resources available within a country but also those from the international community via international cooperation and assistance. ${ }^{215}$

The CESCR has highlighted that States Parties and other actors that can assist should give 'international assistance and cooperation, especially economic and technical', which in turn enables developing countries to meet their core obligations. ${ }^{216}$ Thus, the obligations of international assistance and cooperation are directly related to the obligation to comply with 'core obligations', which ensures the minimum level of the right to health. ${ }^{217}$ These obligations equally correspond to all States Parties to the ICESCR; however, the specific obligations of international assistance and cooperation differ based on the level of development/wealth, ie wealthier States vis-à-vis those States that normally receive assistance and cooperation. ${ }^{218}$ Additionally, the CESCR has arguably broadly interpreted

212 See de Schutter, O, International Human Rights Law (Cambridge University Press, Cambridge, 2010), 172178; CESCR, General Comment No 2, International Technical Assistance, 2 February 1990, E/1990/23.

213 De Schutter, supra nt 212, 162-172; S. Skogly, Beyond National Borders: States' Human Rights Obligations in International Cooperation (Intersentia-Hart, 2006).

214 CESCR, General Comment No. 14, The Right to the Highest Attainable Standard of Health (Art. 12 of the Covenant), 11 August 2000, E/C.12/2000/4, para 39; CESCR, General Comment No. 15, The Right to Water (Arts. 11 and 12 of the Covenant), 20 January 2003, E/C.12/2002, para 31.

215 Sepúlveda, M, “The Obligations of 'International Assistance and Cooperation' under the International Covenant on Economic, Social and Cultural Rights: A Possible Entry Point to a Human Rights Based Approach to Millennium Development Goal 8" 13 International Journal of Human Rights (2009) 87.

216 CESCR, Substantive Issues Arising in the Implementation of the International Covenant on Economic, Social and Cultural Rights: Poverty and the International Covenant on Economic, Social and Cultural Rights, 4 May 2001 E/C.12/2001/10.

217 CESCR, General Comment No 15, supra nt 214 para 38.

218 Sepúlveda, supra nt 215, 89. 
Article 2(1) as also setting up international obligations of assistance and cooperation on entities other than States Parties to the ICESCR, and which can collaborate. ${ }^{219}$

The duty to fulfil or provide requires developed States to give, within the availability of their resources, assistance to other States. ${ }^{220}$ In examining the reports submitted by developed States, the CECSR has strongly encouraged them to reach the target of $0.7 \%$ of their GNP set by the UN. ${ }^{221}$ Concerning the right to health, the CESCR has highlighted that 'depending on the availability of resources, States should [...] provide the necessary aid when required'. ${ }^{22}$ Thus, regarding the right to health, the CESCR has interpreted the need for international assistance and cooperation as an obligation to fulfil or provide, although the CESCR paraphrased it as a recommendation: 'States should'. ${ }^{223}$

In any case, channelling funds from international cooperation and assistance to fully implement medical rehabilitation awards rendered by the ICC, ECCC and IACtHR requires a coordinated effort of developed and developing States. This is consistent with 2000 Millennium Development Goal 8 which calls for the 'creat[ion] [of] a global partnership for development'. Having examined the obligations corresponding to developed States, it is necessary to briefly review those obligations related to developing States. Developing States are expected to seek assistance and, once they have received it, are obliged to establish their own viable development or assistance programmes setting up benchmarks to evaluate performance in realising the right to health. ${ }^{224}$ Benchmarks and indicators enable international monitoring (CESCR, IACtHR) of State obligations to progressively realise the right to health as an economic and social right. Developing States are also obliged to monitor that there is no illegal diversion of resources obtained via international cooperation. ${ }^{225}$ Thus, related risks should be avoided, such as poorly designed health care projects, which may do more harm than good to the beneficiaries of medical rehabilitative reparations.

The international obligations to cooperate and assist to realise the right to health can be directly enforced. This occurs when a developing State ordered by the IACtHR to implement rehabilitative reparations measures receives international cooperation/technical assistance from developed countries to compensate any lack of financial/technical resources. When it comes to the ICC and ECCC, the obligations to cooperate and assist can be indirectly implemented, as international practice has demonstrated. Thus, at the ICC, via donations and contributions of States and other actors to the TFV for both its case-based reparations and assistance mandates, rehabilitative reparations/measures have benefited and/or will benefit a significant number of victims in some of the poorest African countries, such as the DRC, Uganda and CAR. Without this cooperation via the TFV, realising the right to health of victims of international crimes under the ICC's jurisdiction would not be possible. At the ECCC, donations from developed countries made it feasible to meet rehabilitation requests. This would have been impossible if Cambodia had been left alone to

Ibid.

Id, 93.

CESCR, Concluding Observations: France, 30 November 2001, E/C.12/1/Add.72, paras 14, 24.

CESCR, General Comment No 14, supra nt 214, para 40.

Sepúlveda, supra nt 215, 93.

Id, 95.

Id, 96. 
foot the bill for reparations. Thus, these funds channelled via international criminal courts/institutions indirectly fulfil the obligations of international assistance and cooperation concerning the right to health.

Rehabilitative reparations have been, and should be, consistent with international principles and standards on the right to health set up in inter alia the CESCR General Comment No. 14 ('The Right to the Highest Attainable Standard of Health'), considered as follows. In designing and implementing rehabilitative reparations, the following four interrelated and essential elements of the right to health must be considered: ${ }^{226} 1$. availability, ie functioning health care facilities and programmes paying attention to the underlying determinants of health, such as potable water, adequate sanitation facilities, hospitals, clinics, trained personnel, and essential drugs; i2. accessibility, so that health care facilities, goods and services are accessible to every reparations claimant/beneficiary without discrimination, and guaranteeing physical, economic (affordability) and information accessibility; 3. acceptability, ie medical rehabilitative reparations must respect the beneficiaries' culture; and 4. quality, ie rehabilitation of good scientific and medical quality.

Rehabilitative reparations must be guided by the principle of non-discrimination and equal treatment, giving special protection to the most vulnerable members within the universe of reparations claimants. ${ }^{227}$ Thus, access to rehabilitative reparations such as health care excludes any kind of discrimination. ${ }^{228}$ Rehabilitative reparations must also integrate gender perspective approaches, recognising biological and socio-cultural factors, and eliminate discrimination against women concerning access to health care, departing from harmful cultural practices. ${ }^{229}$ Rehabilitative reparations must also consider the child's superior interest as recognised under the Convention on the Rights of Child. Moreover, nondiscrimination, attention to disabilities and abolition of harmful practices need to be implemented for children when designing and implementing rehabilitative reparations. ${ }^{230} \mathrm{As}$ for the elderly, attention should be paid to an integrated approach including preventive, curative and rehabilitative health treatment. ${ }^{231}$ Regarding persons with disabilities, the principle of non-discrimination is also pivotal. ${ }^{232}$ When granting rehabilitative reparations to indigenous people, measures must consider their traditional medical knowledge and relation with their land and environment. ${ }^{233}$

Rehabilitative reparations are needed not only to fulfil the victims' right to health but also other human rights closely linked to it, such as the right to life, non-discrimination, prohibition of torture and medical experimentation, sexual and reproductive freedom and the rights to food and water. ${ }^{234}$ Serious human rights violations/international crimes are grave breaches of basic human rights, including the right to health. Rehabilitative reparations correspond to a wider definition of health that should take into account socially

CESCR, General Comment No 14, supra nt 214, para 12.

Id, para 18.

ICESCR, Articles 2.2 and 3.

CESCR, General Comment No 14, supra nt 214, paras 20 and 21.

Id, para 22 .

$I d$, para 25.

Id, para 26.

Id, para 27.

$I d$, paras 3 and 8. 
related concerns such as violence and armed conflict, ${ }^{235}$ which are the background to massive abuses. As realising the right to health is broader than health care, underlying determinants of health, such as access to safe and potable water, adequate sanitation, and adequate supply of food and nutrition, should also be considered in rehabilitative reparations. ${ }^{236}$

Those principles and standards which orient the obligations of respect, protection and fulfilment of the right to health have to a larger or lesser extent guided the work of the IACtHR, ICC and ECCC when rendering rehabilitative reparations. For example, the ICC A.Ch in its Order for Reparations fleshed out most of these principles and standards. Thus, principles of dignity, non-discrimination, non-stigmatisation together with the principle of the best interests of the child, a gender approach, accessibility, and consultation with victims and their communities were presented as fundamental to rehabilitative reparations in international crimes cases. ${ }^{237}$ The rehabilitative reparations ordered by the IACtHR and ECCC have also been consistent with those principles and standards. ${ }^{238}$ This speaks volumes about a grammar common to rehabilitative reparations across international courts.

Rehabilitative reparations are channels for States to implement directly (IACtHR's reparations) or indirectly (ICC's and ECCC's reparations) their international obligations concerning the right to health. This involves the obligations to respect, protect and fulfil. Particularly, the obligation to fulfil is intertwined with implementation and/or cooperation to implement rehabilitative reparations. Among other features, ${ }^{239}$ provision of a sufficient number of hospitals and other related facilities and trained personnel, with respect for sexual and reproductive health and attention to the needs of vulnerable or marginalised groups, should guide the complex mechanisms of rehabilitative measures. The realisation of the right to health via rehabilitative reparations contributes to fulfil the core contents of the right to health of victims of the most serious atrocities who mainly also belong to the most vulnerable or marginalised groups. Thus, respect for the principle of non-discrimination is also met. Should one consider that States have joint and individual responsibilities under international law to provide disaster relief/humanitarian assistance in times of emergency, ${ }^{240}$ it may be argued that there exists a relatively similar obligation to cooperate with medical rehabilitation of victims of serious human rights violations/international crimes no matter where these may have taken place.

If the respective defendant State does not implement rehabilitative reparations ordered by the IACtHR, this triggers a violation of the right to health. Arguably, States, especially those wealthy enough to cooperate with funding/implementation of rehabilitative reparations ordered by the ICC and ECCC, may violate victims' right to health if they remain inactive. This would be the case if those States are unwilling to use the maximum of their available resources for the realisation of the right to health, omit to adopt necessary measures arising from international obligations affecting the core components of the right to health and, in

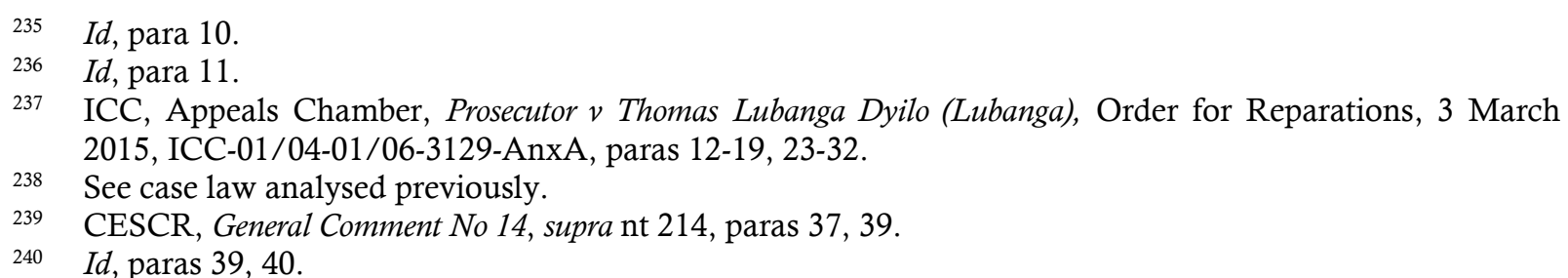


turn, the obligations to respect, protect and fulfil. ${ }^{241}$ Certainly, these obligations primarily compromise a State as for individuals under its jurisdiction. However, considering that rehabilitative reparations at the ICC, ECCC and in some IACtHR cases try to redress harm out of violations of ius cogens rules, such as the prohibitions of genocide, torture or crimes against humanity, the related obligations to realise the right to health arguably include all States.

This of course means cooperation within the respective States' available resources. Indeed, within the remedies and accountability mechanisms to realise the right to health, victims' access to reparations mechanisms is recognised as a key element to implement the right to health. ${ }^{242}$ Moreover, the ICC A.Ch, under the ICC Statute, reminded the ICC Statute States Parties of their obligation to cooperate fully with the enforcement of reparations orders and not to interfere with their implementation. ${ }^{243}$ Other international law subjects such as the UN, other international organisations, and additionally civil society entities, have also been considered actors with obligations to realise the right to health. ${ }^{244}$ This is true when rehabilitative reparations endeavour to address harm causally linked to violations of ius cogens rules and erga omnes obligations, which involve not only all States but also all international law subjects within their differentiated capacities and/or mandates.

\section{Final Assessment and Recommendations}

The following steps and actions should be adopted to increase the impact of medical rehabilitative measures on realising the right to health of victims of international crimes/serious human rights violations.

First, States' role in the successful implementation of rehabilitative reparations, as complemented by other actors of the international community, is crucial. Thus, States which have to implement IACtHR's rehabilitative reparations need to substantially increase their degree of implementation of rehabilitation and, thus, reverse the low rate of implementation of medical rehabilitative reparations which has characterised Latin-America. If the defendant State lacks sufficient resources to proceed with that implementation, it should seek to receive financial/technical assistance from other States, particularly, those developed and also from international organisations. As for rehabilitative reparations granted by the ICC and ECCC, States should and, indeed, must arguably cooperate financially towards the implementation of the respective rehabilitative reparations awards. This cooperation can also be via non-financial or technical means, for example, organising training of medical and health care personnel, helping to build hospitals and other health care facilities, and providing medicines. International and civil society organisations, especially those working on the fulfilment of the right to health, should also contribute with their expertise to joint projects with States or on their own. Thus, these efforts should expedite and enhance the current, on-going process of planning and implementation of rehabilitative reparations awards at the ICC and maximise the good work so far done by the TFV in the field. In turn, the external funding mechanism at the ECCC may be strengthened to avoid previous

\footnotetext{
$241 \quad I d$, paras $47-52$.

$242 I d$, paras 54, 59-62.

243 ICC, Appeals Chamber, Lubanga, Order for Reparations, para 50.

244 CESCR, General Comment No 14, supra nt 214, paras 63-64.
} 
negative outcomes, reduce the delay of rehabilitative reparations implementation and go further, for example, limited not only to mental health but also physical health.

Second, lawyers advising/representing victims in their rehabilitative reparations claims should fully address the core elements of the right to health. Rehabilitative reparations by the IACtHR, ICC and ECCC have generally speaking met the general international principles and standards of the right to health. However, these courts should progressively, in further detail and more explicitly pay attention to specific components of the obligations stemming from the right to health when designing, approving, ordering and/or monitoring rehabilitative reparations. This has to be conducted within their respective mandates. Be that as it may, those three courts should go beyond general references to principles and standards on the right to health. Thus, they should discuss in detail how the obligations of the right to health may be fulfilled via rehabilitative reparations awards (IACtHR), and should seek creative methods to tailor the right to health obligations, originally intended for States, to the reparations systems of international/hybrid criminal courts (ICC, ECCC).

Finally, there must be a synergy of efforts among the institutions examined, as well as others that have the power to order rehabilitative reparations for international crimes/serious human rights violations, for example, the ECtHR and African Court of Human and People's Rights. Indeed, for example, the ICC Statue refers to a complementarity between its own mandate and other mechanisms to provide rehabilitative reparations to the victims. ${ }^{245}$ This corresponds to the fact that the same set of events, the same physical and mental harm inflicted on the health of victims of international crimes/serious human rights violations may be redressed via mechanisms not limited to just one court. For example, if the situation in Colombia under ICC preliminary investigation finally joins the set of situations and cases at the ICC, victims of heinous atrocities in Colombia will be able to claim and receive medical rehabilitation at both the IACtHR and ICC. Thus, it is important to increase the dialogue among regional, national, hybrid and international courts to maximise the positive benefits stemming from rehabilitative reparations on the right to health of a very large number of victims across the world.

\section{www.grojil.org}

